Lesser Sunda

P-ISSN: 2775-0078

Januari 2021

E-ISSN: 2775-0086

Vol. 1(1):1-8

\title{
Keanekaragaman Jenis Plankton pada Akar dan Perairan Sekitar Mangrove Desa Lembar Selatan, Kabupaten Lombok Barat
}

\author{
Ibadur Rahman ${ }^{1 *}$, Chandrika Eka Larasati ${ }^{1}$, Ayu Adhita Damayanti ${ }^{1}$ \\ ${ }^{1}$ Program Studi Ilmu Kelautan, Jurusan Perikanan dan Ilmu Kelautan, \\ Fakultas Pertanian, Universitas Mataram \\ *ibadur.rahman@unram.ac.id
}

Naskah diterima : 1 Desember 2020, Disetujui : 10 Januari 2021

\begin{abstract}
The mangrove ecosystem is one of the ecosystems in the estuary area that is unique and very sensitive to environmental changes. The large number of aquaculture businesses around Cemare Hamlet, West Lombok Regency have resulted in many mangrove areas being converted into pond cultivation locations. This will have an impact on the life of mangrove ecosystems such as plankton. This study aims to determine the abundance of plankton species around the mangrove area of Dusun Cemare, Sheet Selatan Village, West Lombok Regency. The research was conducted in May-October 2019 using a purposive sampling method by determining 7 stations to represent water conditions. Plankton analysis using the Lackey drop microtranscting method. The results showed that the mangrove ecosystem in Dusun Cemare was composed of 4 types, namely: Rhizophora sp., Avicenia sp., Bruguiera sp., And Soneratia sp. The plankton community in mangrove waters is composed of 13 types, while the abundance of plankton species (periphyton) attached to the mangrove roots consists of 6 types. The composition of plankton species which tends to be high indicates that the mangrove waters of Dusun Cemare are still feasible to sustain the survival of the associated biota in it.
\end{abstract}

Keywords : Cemare, mangrove, plankton

\section{PENDAHULUAN}

Ekosistem mangrove merupakan salah satu ekosistem di kawasan estuaria yang khas dan sangat peka terhadap perubahan lingkungan. Mangrove memiliki tingkat produktivitas yang tinggi, sehingga dikenal dengan kawasan yang subur karena dapat menghasilkan bahan organik yang dihasilkan oleh serasah daun-daunnya (Heriyanto, 2012). Serasah tersebut diuraikan oleh bakteri pengurai (detritus) yang menghasilkan unsur hara (nitrogen, fosfor, dan zat hara lainnya) yang kemudian dimanfaatkan oleh mikroorganisme seperti plankton (Layborn \& Parry, 1992).

Plankton merupakan organisme yang berukuran mikroskopis yang banyak ditemukan diseluruh perairan terutama disekitar kawasan mangrove (Halidah, 2016). Plankton berperan penting dalam menghasilkan energi bagi organisme lain dalam suatu ekosistem. Tinggi atau rendahnya kelimpahan plankton akan mempengaruhi siklus hidup dalam ekosistem 
perairan. Kelimpahan plankton yang rendah akan berpengaruh pada kehidupan ikan, mangrove, dan manusia yang menjadikan laut sebagai sumber mata pencaharian. (Halidah, 2016).

Dusun Cemare merupakan sebuah dusun di Desa Lembar Selatan, Kabupaten Lombok Barat, yang berada pada daerah estuary yang mana adanya pertemuan sungai dan air laut yang masuk dari Teluk Lembar. Banyaknya usaha budidaya perikanan disekitar dusun tersebut, maka kawasan mangrove banyak yang dialihfungsikan menjadi lokasi budidaya tambak. Hal tersebut dapat menyebabkan terjadinya abrasi, yang mana akan hilang peranan mangrove sebagai penahan ombak. Selain itu mangrove memiliki fungsi biologi sebagai tempat mencari makan, memijah, dan bahkan sebagai tempat pembesara bagi berbagai biota seperti plankton, nekton (ikan), dan benthos (udang, teripang, kepiting) (Halidah, 2016). Oleh karena itu, perlu diketahui kelimpahan jenis plankton di kawasan mangrove Desa Lembar Selatan, Kabupaten Lombok Barat. Kelimpahan jenis plankton yang didapat dikaitkan dengan kondisi lingkungan di sekitar kawasan mangrove.

\section{METODE PENELITIAN}

Penelitian ini dilaksanakan pada Bulan Mei-Oktober 2019 di perairan mangrove Dusun Cemare, Desa Lembar Selatan, Kecamatan Lembar, Kabupaten Lombok Barat (Gambar 1). Penelitian ini menggunakan metode purposive sampling dengan menentukan 7 stasiun untuk mewakili kondisi perairan. Identifikasi jenis plankton dilakukan di Laboratorium Bioekologi Perairan, Program Studi Budidaya Perairan,
Fakultas Pertanian, Universitas Mataram Analisis kualitas perairan dilakukan di Laboratorium Kimia Analitik Fakultas Matematika dan Ilmu Pengetahuan Alam (FMIPA) Universitas Mataram.

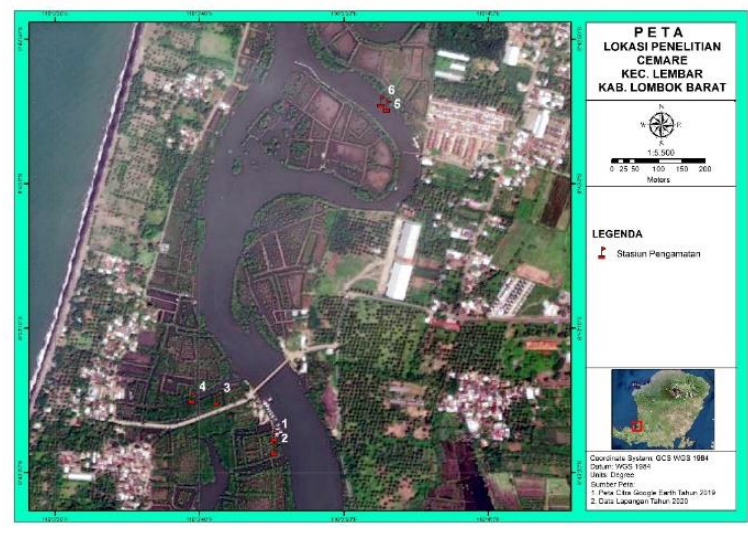

Gambar 1 Peta Lokasi penelitian

\section{a. Kerapatan Jenis Mangrove}

Analisis vegetasi mangrove dalam kegiatan penelitian ini dilakukan dengan metoda kombinasi antara metoda jalur dan metoda garis berpetak (Gambar 2) yang diletakkan tegak lurus garis pantai menuju daratan dengan lebar $10 \mathrm{~m}$ dan panjangnya tergantung kondisi lapangan (Kusmana, 1997).

Ukuran permudaan yang digunakan dalam kegiatan analisis vegetasi hutan mangrove adalah sebagai berikut:

(a) Semai : Permudaan mulai dari kecambah sampai anakan setinggi $<1,5 \mathrm{~m}$.

(b) Pancang : Permudaan dengan tinggi 1,5 m sampai anakan berdiameter kurang dari $10 \mathrm{~cm}$.

(c) Pohon : Pohon berdiameter $10 \mathrm{~cm}$ atau lebih. 
(d) Tumbuhan bawah : Tumbuhan selain permudaan pohon, misal rumput, herba dan semak belukar

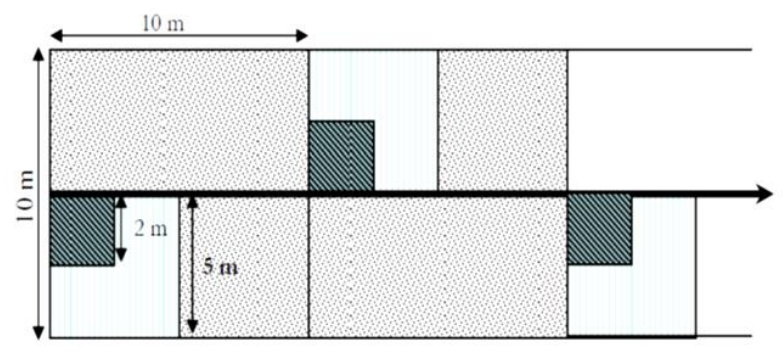

Gambar 2 Layout transek mangrove

\section{b. Kelimpahan Jenis Plankton}

Kelimpahan jenis plankton yang diambil yaitu jenis plankton di kolom perairan dan yang menempel pada akar mangrove. Pada sampel plankton di perairan diperoleh dengan mengambil contoh air laut sebanyak 100 liter dipermukaan perairan yang disaring menggunakan plankton net (mesh size $20 \mu \mathrm{m}$ ) sebanyak $100 \mathrm{ml}$. Kemudian diberikan larutan lugol 1\% sebanyak 4 tetes (Sahu et al, 2012). Kelimpahan jenis plankton diperairan dihitung dengan menggunakan metode APHA, 2005 dengan menggunakan Sedgwick rafter cell. Pengamatan plankton menggunakan mikroskop dengan merk Olympus CX21 dengan perbesaran 100X. Identifikasi plankton mengacu pada bu Davis (1955), Yamaji (1966), dan Hasle et al, 1996.

Sampel plankton pada akar mangrove diperoleh dengan merendam akar dalam plastic yang telah diberi label dengan larutan lugol. Kemudian akar mangrove diletakkan diatas wadah/cawan.Pastikan tidak ada yang tersisa didalam plastik. Apabila masih ada sisa kotoran atau kulit akar dalam plastic, lakukan pembilasan dengan akuades. Kemudian air pembilasan dituang kembali ke botol sampel. Sampel plankton yang melekat pada akar mangrove disikat secara perlahan dan merata diatas cawan dan disemprot akuades secara perlahan hingga bersih. Air yang berada pada cawan dimasukkan kembali ke botol sampel. Kocok terlebih dahulu botol sampel agar homogen. Amati plankton dibawah mikroskop menggunakan Sedgwick rafter cell (SRC) dengan metode Lackey drop microtranscting method (APHA, 2005).

\section{c) Parameter Kualitas Air}

Parameter kualitas air yang akan diukur pada masing-masing stasiun penelitian yaitu suhu, $\mathrm{pH}$, nitrat, fosfat, salinitas, dan arus. Parameter suhu, $\mathrm{pH}$, arus dan salinitas akan diukur secara langsung (di lapangan) sedangkan nitrat dan fosfat akan diukur di laboratorium kimia analitik FMIPA Universitas Mataram.

\section{HASIL DAN PEMBAHASAN}

\section{a. Kerapatan Jenis Mangrove}

Terdapat 4 jenis mangrove yang ditemukan di Dusun Cemare, yaitu: Rhizophora sp., Avicenia sp., Bruguiera sp., dan Soneratia sp. (Gambar 3). Rhizophora sp. merupakan jenis mangrove yang selalu ditemukan di setiap stasiun penelitian, dengan nilai kerapatan yang berbeda-beda. Jenis mangrove Avicenia sp. ditemukan di stasiun 2 (8 ind $\left./ 100 \mathrm{~m}^{2}\right), 4$ ( $\left.2 \mathrm{ind} / 100 \mathrm{~m}^{2}\right)$ dan 5 (1 ind $\left./ 100 \mathrm{~m}^{2}\right)$. Jenis Bruguiera sp. hanya ditemukan di stasiun 2 dan 7 dengan kerapatan yang sama besar yaitu 2 ind $/ 100 \mathrm{~m}^{2}$. Sedangkan jenis mangrove Soneratia sp. hanya ditemukan di stasiun 1 (1 ind $\left./ 100 \mathrm{~m}^{2}\right)$ dan $5\left(2 \mathrm{ind} / 100 \mathrm{~m}^{2}\right)$. 


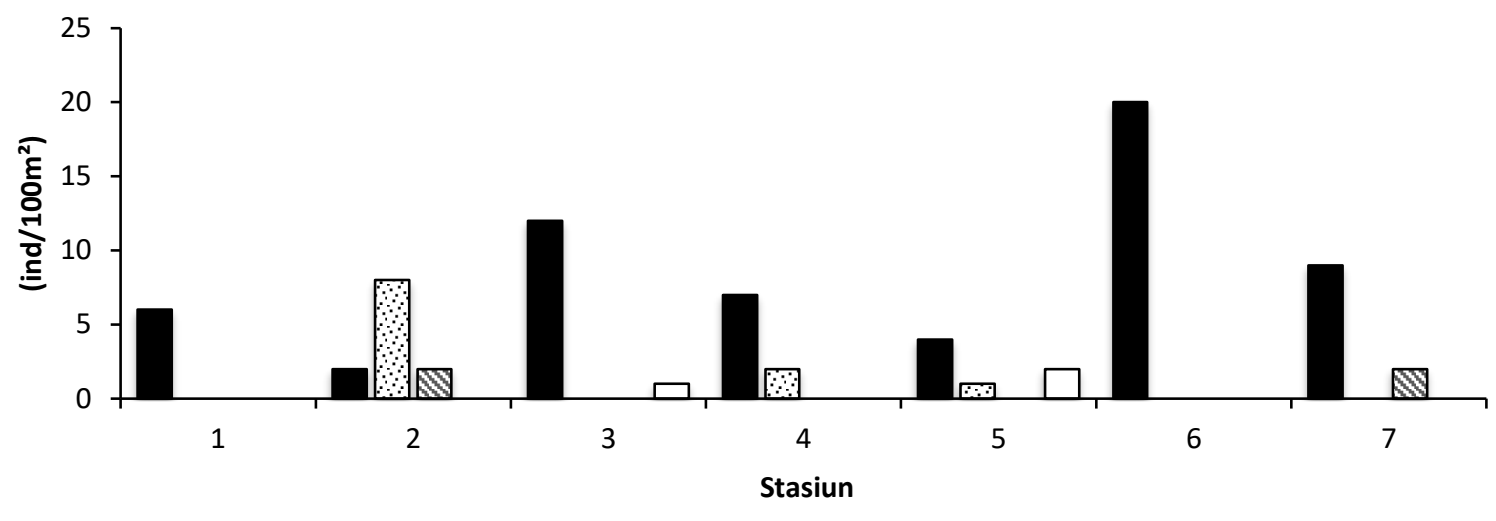

- Rhizopora sp. $\square$ Avicenia sp. B Bruguiera sp. $\square$ Soneratia sp.

Gambar 3 Kerapatan jenis mangrove di Dusun Cemare

Tingginya kerapatan mangrove jenis Rhizophora sp. dan selalu ditemukannya jenis ini ini di setiap stasiun penelitian diduga dikarenakan dulunya kawasan mangrove Dusun Cemare merupakan area tambak yang kemudian digalakkan program penanaman (rehabilitasi) mangrove khususnya jenis Rhizophora sp. yang memiliki akar tunjang yang cocok dengan karakteritik perairan sekitar muara sungai Dusun Cemare. Hal serupa juga ditemukan oleh Hariyati et al. (2009) pada kawasan mangrove di muara sungai banjir kanal timur Semarang, Jawa Tengah.

\section{b. Kerapatan Relatif Mangrove}

Kerapatan relatif mangrove merupakan besaran persentase/proporsi jenis mangrove tertentu dibandingkan total seluruh jenis mangrove yang terdapat di suatu lokasi. Jenis Rhizophora sp. merupakan jenis mangrove tunggal yang ditemukan pada stasiun 1 dan 6 sehingga persentasenya mencapai 100\% (Gambar 4). Stasiun 2 terdiri dari 3 jenis mangrove, yaitu: Rhizophora sp. (17\%), Avicenia sp. (67\%) dan Bruguiera sp. (17\%). Stasiun 3 tersusun atas 2 jenis mangrove yaitu Rhizophora sp. (92\%) dan Soneratia sp. (8\%). Stasiun 4 tersusun atas 2 jenis yaitu Rhizophora sp. (78\%) dan Avicenia sp. (22\%). Stasiun 5 tersusun atas 3 jenis mangrove, yaitu: Rhizophora sp. (57\%), Avicenia sp. (14\%) dan Sonertia sp. (29\%). Sedangkan stasiun 7 tersusun dari 2 jenis mangrove, yaitu Rhizophora sp. (82\%) dan Bruguiera sp. (18\%). 


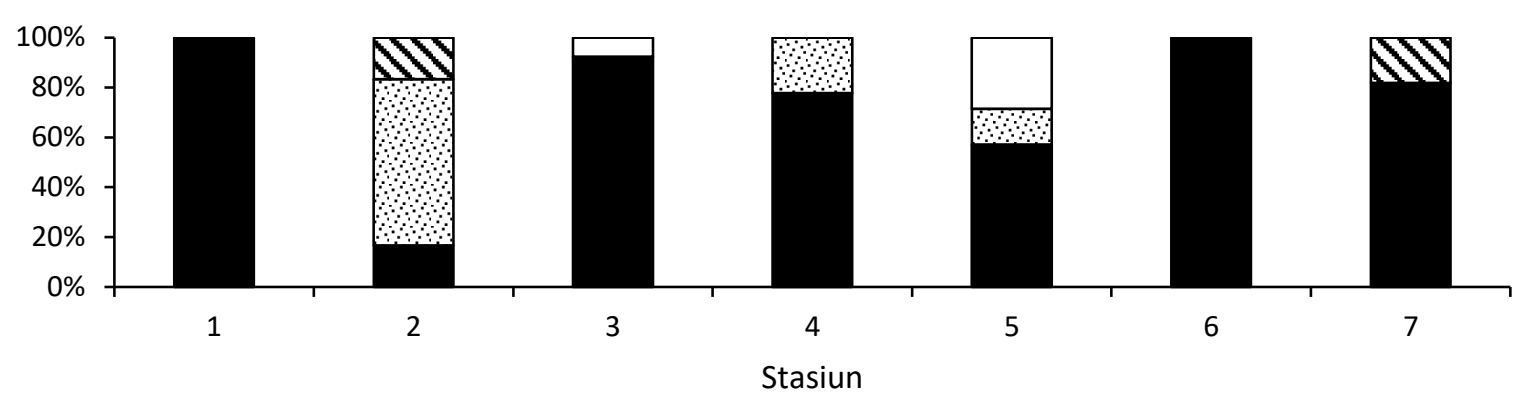

Rhizopora sp. $\square$ Avicenia sp. $\quad$ Bruguiera sp. $\square$ Soneratia sp.

Gambar 4 Kerapatan relatif mangrove Dusun Cemare

\section{c. Kelimpahan Jenis Plankton}

Kelimpahan jenis plankton terbagi atas kelimpahan jenis plankton di permukaan perairan dan menempel di akar mangrove. Terdapat 13 jenis plankton yang ditemukan di permukaan perairan mangrove Dusun Cemare, yaitu: Biddulphia (Bi), Cocconeis (Co), Coscinodiscus (Cs), Diploneis (Di), Fibrocabsa (Fb), Gyrosigma (Gy), Licmophora sp. (Li), Navicula sp. (Na),

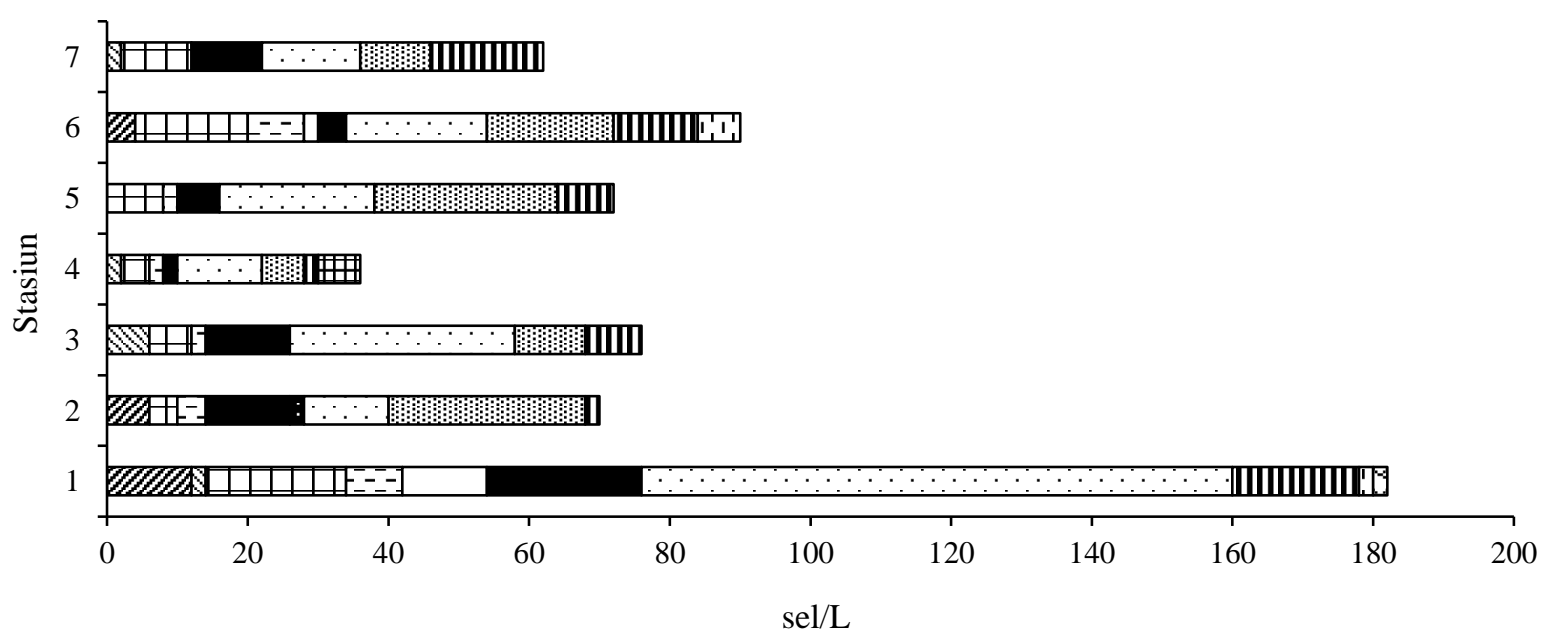

$\boldsymbol{\nabla}$ (Bi) Biddulphia $\square(\mathrm{Fb})$ Fibrocabsa (Ni) Nitzschia 凹(Th) Thalassionema
Nitzschia (Ni), Pleurosigma sp. (Pl), Rhizosolenia sp. (Rh), Skeletonema costatum (Sk), dan Thalassionema (Th). Jenis plankton yang memiliki nilai kelimpahan rata-rata tertinggi yaitu Navicula sp. (28 sel/L), sedangkan jenis plankton yang memiliki kelimpahan rata-rata terendah yaitu jenis Licmophora sp. dan Skeletonema costatum (1 sel/L) (Gambar 5).

$\operatorname{sel} / \mathrm{L}$

$$
\begin{aligned}
& \text { ⿶(Co) Cocconeis } \\
& \text {-(Gy) Gyrosigma } \\
& \text { Ш (Pl) Pleurosigma sp. }
\end{aligned}
$$

$\square(\mathrm{Cs})$ Coscinodiscus

-(Li) Licmophora

$\square(\mathrm{Rh})$ Rhizosolenia sp.
曰(Di) Diploneis $\square(\mathrm{Na})$ Navicula sp. $\boldsymbol{\theta}(\mathrm{Sk})$ Skeletonema costatum

Gambar 5 Kelimpahan jenis plankton di perairan mangrove Dusun Cemare 
Kelimpahan plankton jenis Navicula sp. di perairan mangrove diduga dikarenakan jenis plankton ini dapat beradaptasi dengan baik pada lingkungan perairan mangrove. Hariyati et al. (2009) menyatakan bahwa Navicula sp. merupakan jenis plankton air tawar yang cukup dominan di kawasan mangrove, disebabkan oleh ekosistem mangrove cenderung dipengaruhi oleh masuknya air tawar. Selain itu ketersediaan nutrient dapat berasal dari komponen biotik yang berada dari ekosistem mangrove, seperti serasah mangrove yang dapat meningkatkan kelimpahan jenis plankton tersebut (Qiptiyah et al, 2008; Kordi, 2012).

Pada Stasiun 1 terdapat jenis kelimpahan plankton yang lebih banyak dibandingkan dengan stasiun lainnya. Hal ini tak terlepas dari keberadaan mangrove jenis Rhizopora yang memiliki perakaran yang kuat sehingga ombak relatif lebih tenang dan menyebabkan jenis plankton akan berkembangbiak dengan baik dan melimpah (Aini et al, 2018).
Plankton (perifiton) yang menempel di perakaran tumbuhan mangrove memiliki jenis dan kelimpahan yang lebih rendah dibandingkan yang ditemukan di permukaan perairan mangrove. Dalam penelitian ini hanya ditemukan 6 (enam) jenis plankton yang menempel di perakaran mangrove, yaitu: Cylindrotheca (Cy), Diploneis (Di), Licmophora (Lc), Navicula sp. (Na), Nitzschia (Ni), dan Pleurosigma (Pl). Jenis plankton yang memiliki nilai kelimpahan rata-rata tertinggi yaitu jenis Nitzschia sebanyak 23 sel/L, sedangkan jenis yang memiliki nilai kelimpahan rata-rata terendah yaitu jenis Diploneis sebanyak 3 sel/L (Gambar 6). Jenis Nitzschia banyak ditemukan disekitar perakaran mangrove karena termasuk ke dalam ordo pennales yang mana ordo tersebut banyak ditemukan didasar perairan ataupun menempel disubstrat dan akar.

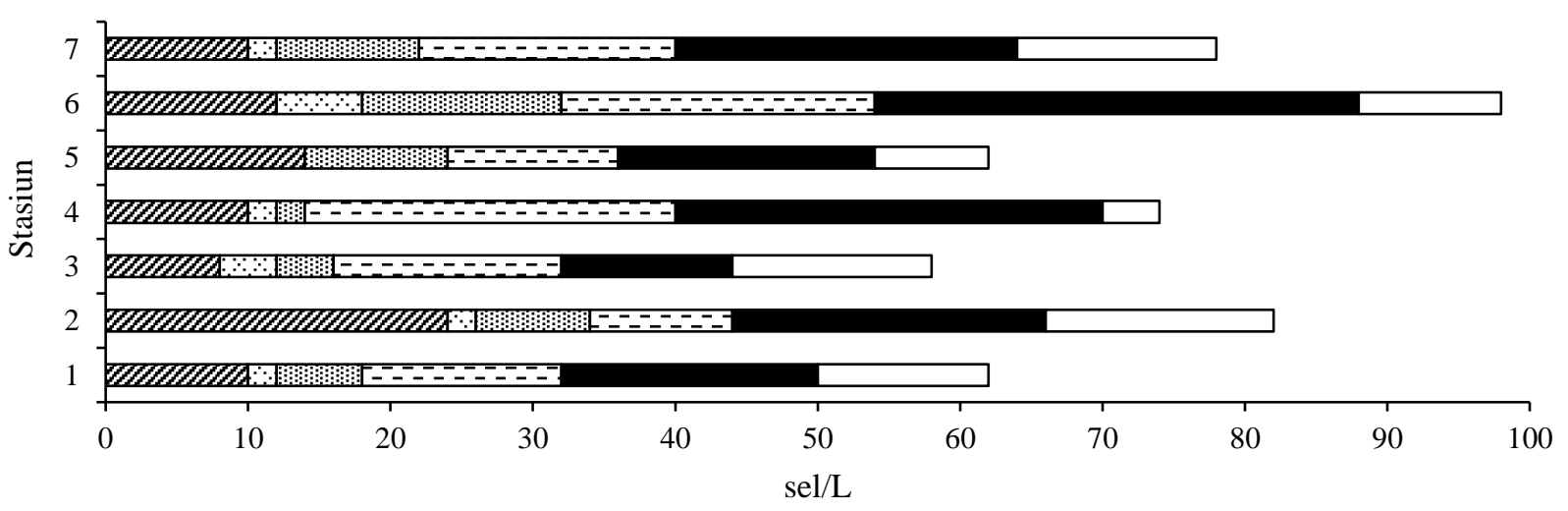

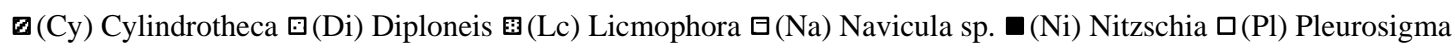

Gambar 6 Kelimpahan jenis plankton (perifiton) pada akar mangrove di Dusun Cemare 


\section{d. Kualitas Perairan Mangrove}

Terdapat 7 (tujuh) parameter kualitas air yang diamati di perairan sekitar mangrove Dusun Cemare, meliputi kedalaman, derajat keasaman $(\mathrm{pH})$, kandungan oksigen terlarut (DO), suhu, salinitas, nitrat dan fosfat. Kedalaman perairan sekitar mangrove berkisar antara $0,18-0,6 \mathrm{~m}$. $\mathrm{pH}$ berkisar antara 5,5-8,5, DO berkisar antara $6-9,6$ $\mathrm{mg} / \mathrm{l}$, suhu berkisar antara $30,7-32,8{ }^{\circ} \mathrm{C}$, salinitas berkisar antara $25-31$ ppt. Kandungan nitrat berkisar antara 0,003-013 $\mathrm{mg} / \mathrm{l}$, dan kandungan fosfat berkisar antara 0,017-0,033 mg/l (Tabel 1).

Berdasarkan pengukuran parameter kualitas air sebagaimana disebutkan dalam Tabel 2, diketahui bahwa kualitas perairan mangrove kawasan Dusun Cemare masih tergolong cukup baik dan dapat mendukung kelangsungan hidup organisme laut di perairan Cemare khususnya mangrove dan plankton.

Tabel 1 Nilai parameter kualitas air di perairan mangrove

\begin{tabular}{lcccccccc}
\hline \multirow{2}{*}{ Parameter } & \multirow{2}{*}{ Satuan } & \multicolumn{7}{c}{ Stasiun } \\
\cline { 3 - 9 } & & 1 & 2 & 3 & 4 & 5 & 6 & 7 \\
\hline Kedalaman & $\mathrm{m}$ & 0.32 & 0.25 & 0.35 & 0.18 & 0.6 & 0.55 & 0.52 \\
$\mathrm{pH}$ & - & 6.8 & 5.5 & 7.6 & 6.7 & 8.5 & 8.1 & 7.6 \\
DO & $\mathrm{mg} / 1$ & 6 & 9.6 & 8.5 & 8.9 & 9.7 & 9.1 & 7.1 \\
Suhu & ${ }^{\circ} \mathrm{C}$ & 30.7 & 33.6 & 31.1 & 32.6 & 32.6 & 32.8 & 31.5 \\
Salinitas & $\mathrm{ppt}$ & 30 & 25 & 31 & 31 & 25 & 27 & 30 \\
Nitrat & $\mathrm{mg} / 1$ & 0 & 0.003 & 0.011 & 0.008 & 0.013 & 0.01 & 0.034 \\
Fosfat & $\mathrm{mg} / \mathrm{l}$ & 0 & 0.032 & 0.033 & 0.017 & 0.021 & 0.033 & 0.018 \\
\hline
\end{tabular}

\section{KESIMPULAN}

Terdapat 13 jenis plankton yang ditemukan di permukaan perairan mangrove Dusun Cemare antara lain: Biddulphia, Cocconeis, Coscinodiscus, Diploneis, Fibrocabsa, Gyrosigma, Licmophora sp., Navicula sp., Nitzschia, Pleurosigma sp., Rhizosolenia sp., Skeletonema costatum, dan Thalassionema. Jenis Navicula sp. merupakan jenis dengan kelimpahan rata-rata tertinggi. Di samping itu, ditemukan 6 jenis plankton (perifiton) yang menempel pada perakaran mangrove, yaitu: Cylindrotheca, Diploneis, Licmophora, Navicula sp., Nitzschia, dan Pleurosigma, dimana jenis
Nitzschia memiliki kelimpahan rata-rata tertinggi.

\section{UCAPAN TERIMA KASIH}

Penulis mengucapkan terimakasih yang sebesar-besarnya kepada Universitas Mataram yang telah memberikan bantuan sarana dan prasarana yang mendukung terselenggaranya kegiatan penelitian ini, diantaranya fasilitas Laboratorium Kimia Analitik FMIPA dan Laboratorium Bioekologi Perairan Jurusan Perikanan dan Ilmu Kelautan. Terimakasih juga kami sampaikan kepada mahasiswa program studi budidaya perairan yang banyak membantu 
dalam kegiatan survei dan pengambilan sampel penelitian.

\section{DAFTAR PUSTAKA}

Aini YQ, Al Idrus A, Japa L. 2018. Komunitas Plankton Pada Perairan Habitat Mangrove Di Gili Sulat Lombok Timur. Prosiding Seminar Nasional Pendidikan Biologi (ISBN: 978-602-61265-2-8).

APHA. 2005. Standard methods for the examination of water and waste water. American Public Health Association, American Water Works Association, and Water Pollution Control Federation. 21th edition. Washington D.C. (US).

Bengen DG. 2000. Sinopsis Ekosistem dan Sumber Daya Alam Pesisir. Pusat Kajian Sumberdaya Pesisir dan Lautan - Institut Pertanian Bogor. Bogor.

Cox GW. 1967. Laboratory manual of general ecology. W. M.c. Brown Comp.

Davis C. 1955. The marine and freshwater plankton. Chicago (USA): Michigan State University Press.

Halidah. 2016. Keanekaragaman Plankton Pada Hutan Mangrove Di Kepulauan Togean Sulawesi Tengah. Info Teknis EBONI vol 13(1): 37-44.

Hariyati R, Suprobowati RT, Chotidjah. 2009. Persebaran diatom epipelik secara vertikal pada ekosistem mangrove muara sungai banjir kanal timur Semarang. Buletin Anatomi dan Fisiologi Vol 17 (1).
Hasle G, Syvertsen E, Steidinger K, Tangen K. 1996. Identifying marine diatoms and dinoflagellates. San Diego (California): Academic Press, Inc.

Heriyanto NM. 2012. Keragaman Plankton dan Kualitas Perairan di hutan Mangrove. Buletin Plasma nutfah vol 18(1): $38-44$

Kordi MGH. 2012. Ekosistem Mangrove: Manfaat, Fungsi, dan Pengelolaan. Jakarta (ID): Rineka Cipta.

Kusmana C. 1997. Metode survey vegetasi. IPB Press. Bogor

Layborn J, Parry. 1992. Protozoan Plankton Ecology. Chapman \& Hall, 2-6 Boundary Row, London. p. 1-30

Odum EP. 1993. Dasar-Dasar Ekologi (3th). (Terj.). Yogyakarta: Gajah Mada University Press.

Qiptiyah M, Halidah, Rakhman MA. 2008. Struktur Komunitas Plankton Di Perairan Mangrove dan Perairan Terbuka di Kabupaten Sinjai, Sulawesi Selatan. Jurnal Penelitian Hutan dan Konservasi Alam Vol.5(2):137-143.

Sahu G, Satpathy K, Mohanty A, Sarkar S. 2012. Variations in community structure of phytoplankton in relation to physicochemical properties of coastal waters, southeast coast of India. Indian J. Geo Mar. Sci. 41(3):223-241.

Yamaji I. 1966. Illustration of marine plankton of Japan. Osaka (Japan): Hoikusha Publishin Co. Ltd. 